\title{
PENINGKATAN KETERAMPILAN MENGKOMUNIKASIKAN MELALUI PERMAINAN SAINS DI KELOMPOK B RA AL-ISTIQOMAH KOTA TASIKMALAYA
}

\author{
Vivi Kafilatul Janah ${ }^{1}$, Edi Hendri Mulyana ${ }^{2}$, dan Elan ${ }^{3}$ \\ ${ }^{1}$ Program Studi PGPAUD UPI Kampus Tasikmalaya \\ ${ }^{2}$ Program Studi PGPAUD UPI Kampus Tasikmalaya \\ ${ }^{3}$ Program Studi PGPAUD UPI Kampus Tasikmalaya \\ E-mail: vivikafilla@gmail.com
}

(Received: Nopember 2019; Accepted: Nopember 2019; Published: Desember 2019)

\begin{abstract}
This study is based ob the background behind the learning process that is less varied and the skill of communicating children is still low. Enthusiastic children to communicate what has been observed and done is still very lacking, children only communicate verbally. Though the process of communicating can be conveyed nonverbally, for example images, movements, and tables. Based on observations, the teacher also gives less opportunities for children to try and express their opinions. The media used is also very limited, so the learning process becomes less fun for children. Even though scientific learning should be a fun learning for children because children can try the media in the scientific learning activities. The purpose of this study was to improve the communication skills in class B RA Al-Istiqomah in Tasikmalaya City. This study uses Classroom Action Research (CAR). This study was conducted in three cycles using the Kemmis Mc model. Taggart. The research subjects were children of group B RA Al-Istiqomah in Tasikmalaya City totaling 16 children. The object of this research is the skill to communicate. Rainbow Water science games are games used in learning to improve communication skills. Data collection techniques use documentation and documentation, while data analysis techniques use quantitative descriptive. The instrument used is a structured observation sheet with the achievement of indicators for each activity. The results of the research that have been carried out show that there is an increase in the skills of communicating through science games. This is evidenced by an increase in the ability of teachers to plan learning, the ability of teachers in the process of implementing learning through science games from each cycle. The final result of the skill in communicating the child is in good criteria, the end result of the teacher's ability to plan learning is in very good criteria, and the end result of the teacher's ability to carry out the learning is in very good criteria.
\end{abstract}

Keywords: Communicating Skills, Science Games

\begin{abstract}
ABSTRAK
Penelitian ini di latar belakangi dari proses pembelajaran yang kurang variatif dan keterampilan mengkomunikasikan anak masih rendah. Antusias anak untuk mengkomunikasikan apa yang telah diamati dan dilakukannya masih sangat kurang, anak hanya mengkomunikasikan dengan cara verbal. Padahal proses mengkomunikasikan dapat disampaikan secara nonverbal, misalnya gambar, gerakan, dan tabel. Berdasarkan pengamatan, guru juga kurang memberi kesempatan anak untuk mencoba dan mengeluarkan pendapatnya. Media yang digunakan juga sangat terbatas, sehingga proses pembelajaran menjadi kurang menyenangkan bagi anak. Padahal seharusnya pembelajaran saintifik merupakan pembelajaran yang menyenangkan bagi anak karena anak dapat mencoba media dalam kegiatan pembelajaran saintifik tersebut. Tujuan penelitian ini adalah untuk meningkatkan keterampilan mengkomunikasikan di kelas B RA Al-Istiqomah Kota Tasikmalaya. Penelitian ini menggunakan Penelitian Tindakan Kelas (PTK). Penelitian ini dilaksanakan sebanyak tiga siklus dengan menggunakan model Kemmis Mc. Taggart. Subjek penelitian adalah anak kelompok B RA Al-Istiqomah Kota Tasikmalaya yang berjumlah 16 anak. Objek penelitian ini adalah keterampilan mengkomunikasikan. Permainan sains Rainbow Water adalah permainan yang digunakan dalam pembelajaran untuk meningkatkan keterampilan mengkomunikasikan. Teknik pengumpulan data menggunakan dokumentasi dan dokumentasi, Sedangkan teknik analisis data menggunakan deskriptif kuantitatif. Instrument yang digunakan berupa lembar observasi terstruktur dengan capaian indikator setiap kegiatannya. Hasil penelitian yang telah dilaksanakan menunjukkan bahwa adanya peningkatan keterampilan mengkomunikasikan melalui permainan sains.
\end{abstract}

Kata kunci : Keterampilan Mengkomunikasikan, Permainan Sains 


\section{PENDAHULUAN}

Menurut Undang-undang Nomor 20 Tahun 2003 tentang Sistem Pendidikan Nasional Pasal 1 ayat 14 Pendidikan Anak Usia Dini adalah suatu upaya pembinaan yang ditujukan kepada anak sejak lahir sampai dengan usia 6 tahun yang dilakukan melalui pemberian rangsangan pendidikan untuk membantu pertumbuhan dan perkembangan jasmani dan rohani agar memiliki kesiapan dalam memasuki pendidikan lebih lanjut. Menurut Yuliani Nurani Sujiono (2013, hlm. 38) usia dini adalah

“ Masa dimana anak mengalami masa keemasan atau golden ages. Anak usia dini adalah sosok individu yang sedang menjalani suatu proses perkembangan dengan pesat dan fundamental bagi kehidupan selanjutnya. Anak usia dini berada pada rentang 0-6 tahun, usia ini merupakan usia yang sangat menentukan dalam pembentukan karakter dan kepribadian seorang anak".

Masa kanak-kanak adalah masa pertumbuhan dan perkembangan yang sangat pesat. Dalam pembelajaran di TK guru mempersiapkan kegiatan pembelajaran sesuai dengan tahap perkembangan anak. Kemampuan dasar yang dikembangkan adalah bahasa, kognitif, sosial-emosional, fisik-motorik, dan seni. Aspek kognitif dapat mengembangkan kemampuan berpikir anak untuk memecahkan suatu masalah yang diperoleh, serta membantu anak untuk mengembangkan kemampuan matematika dan kemampuan sains.

Sains adalah proses, produk, dan sikap. Sains sebagai proses, sains mencakup kegiatan menelusuri, mengamati dan melakukan percobaan. Sains sebagai produk, sains adalah pengetahuan yang terorganisir dengan baik mengenai dunia fisik alami. Sains sebagai suatu sikap, atau dikenal dengan istilah sikap keilmuan, maksudnya berbagai keyakinan, opini dan nilai-nilai yang harus dipertahankan oleh seorang ilmuan khususnya ketika mencari atau mengembangkan pengetahuan baru.

Pengembangan keterampilan proses sains siswa diperlukan dalam menjelajah dan memahami alam sekitar. Keterampilan proses siswa dikembangkan agar siswa terbiasa untuk menemukan suatu fakta dan konsep sendiri seiring dengan perkembangan ilmu pengetahuan yang berlangsung semakin cepat, untuk melatih anak berfikir dan bertindak secara kreatif, untuk melatih anak dalam mengembangkan pikiran (kognitif) melalui gerakan dan perbuatan serta untuk mengembangkan sikap dan nilai pada diri anak sehingga menghasilkan pribadi yang manusiawi (Conny Semiawan, 1986, hlm. 18).

Proses pembelajaran pada kurikulum 2013 untuk semua jenjang dilaksanakan dengan menggunakan pendekata ilmiah (saintifik). Langkah-langkah pendekatan ilmiah dalam proses pembelajaran meliputi mengamati (observasi), menanya, mengumpulkan informasi, mengasosiasikan/mengolah

informasi/menalar,

dan mengkomunikasikan.

Pada pendekatan saintifik guru diharapkan memberi kesempatan kepada anak untuk mengkomunikasikan apa yang telah mereka pelajari. Kegiatan ini dapat dilakukan melalui menuliskan atau menceritakan apa yang di temukan dalam kegiatan mencari informasi. Hasil tersebut disampaikan didepan guru dan teman-temannya. Permendikbud Nomor 81 A Tahun 2013 menyampaikan bahwa kegiatan mengkomunikasikan dalam kegiatan pembelajaran adalah menyampaikan hasil pengamatan, kesimpulan berdasarkan hasil analisis secara verbal dan non verbal. 
Berdasarkan pengamatan terhadap kegiatan pembelajaran saintifik di RA Al-Istiqomah ditemukan beberapa masalah. Pembelajaran kurang variatif dan keterampilan mengkomunikasikan anak masih rendah. Antusias anak untuk mengkomunikasikan apa yang telah diamati dan dilakukannya masih sangat kurang, anak hanya mengkomunikasikan dengan cara verbal. Padahal proses mengkomunikasikan dapat disampaikan secara nonverbal, misalnya gambar, gerakan, dan tabel. Berdasarkan pengamatan, guru juga kurang memberi kesempatan anak untuk mencoba dan mengeluarkan pendapatnya. Media yang digunakan juga sangat terbatas, sehingga proses pembelajaran menjadi kurang menyenangkan bagi anak. Padahal seharusnya pembelajaran saintifik merupakan pembelajaran yang menyenangkan bagi anak karena anak dapat mencoba media dalam kegiatan pembelajaran saintifik tersebut.

Oleh karena itu, salah satu solusi yang ditawarkan adalah dengan menggunakan permainan dalam pembelajaran. Permainan yang diberikan yaitu permainan sains yang berkaitan dengan keterampilan mengamati, karena kegiatan mengkomunikasikan adalah kegiatan yang dapat dilakukan setelah anak melakukan pengamatan. Dengan permainan tersebut diharapkan anak memiliki pengalaman yang bermakna dan menyenangkan.

Berdasarkan masalah yang telah dipaparkan, peneliti akan melakukan penelitian dengan judul Peningkatan Keterampilan Mengkomunikasikan melalui Permainan Sains di Kelas B RA Al-Istiqomah Kota Tasikmalaya.

\section{TINJAUAN PUSTAKA}

\subsection{Keterampilan Sainstifik}

\subsubsection{Pengertian Keterampilan Saintifik}

Keterampilan saintifik/proses sains adalah keterampilan siswa untuk mengelola hasil yang didapat dalam kegiatan belajar mengajar yang memberi kesempatan seluas-luasnya kepada siswa untuk mengamati, menggolongkan, menafsirkan, meramalkan, menerapkan, merencanakan penelitian dan mengkomunikasikan (Semiawan, 1992, hlm. 28). Keterampilan saintifik merupakan keterampilan yang melibatkan keterampilan kognitif, manual, dan sosial. Kognitif terlibat karena anak dituntut untuk berpikir dalam keterampilan proses sains. Keterampilan manual terlibat karena anak menggunakan alat dan bahan, keterampilan sosial juga terlibat karena anak berkomunikasi dengan orang lain dalam melakukan kegiatan.

\subsubsection{Pendekatan Saintifik}

Dalam kurikulum 2013 PAUD, pendekatan saintifik adalah proses pembelajaran yang dirancang sedemikian rupa agar peserta didik secara aktif membangun kompetensi sikap, pengetahuan, dan keterampilan melalui tahapan mengamati, menanya, mengumpulkan informasi, menalar, dan mengkomunikasikan.

Berikut ini merupakan proses pelaksanaan pendekatan saintifik PAUD:

1. Mengamati

Mengamati dilakukan untuk mengetahui objek diantaranya dengan menggunakan indera seperti melihat, membaca buku, mendengar, menghidu, merasa, dan meraba.

2. Menanya

Anak didorong untuk bertanya, baik tentang objek yang telah diamati maupun hal-hal lain yang ingin diketahui. 
3. Mengumpulkan informasi

Mengumpulkan informasi dilakukan melalui beragam cara, misalnya, dengan melakukan, mencoba, mendiskusikan, membaca buku, menanya, dan menyimpulkan hasil dari berbagai sumber.

4. Menalar

Menalar merupakan kemampuan menghubungkan informasi yang sudah dimiliki dengan informasi yang baru diperoleh sehingga mendapatkan pemahaman yang lebih baik tentang suatu hal.

5. Mengkomunikasikan

Mengkomunikasikan merupakan kegiatan untuk menyampaikan halhal yang telah dipelajari dalam berbagai bentuk, misalnya melalui cerita,gerakan, dan dengan menunjukkan hasil karya berupa gambar, berbagai bentuk dari adonan, boneka dari bubur kertas, kriya dari bahan daur ulang, dan hasil anyaman.

\subsubsection{Keterampilan mengkomunikasikan}

Keterampilan mengkomunikasikan adalah tahap ke lima dari serangkaian tahapan pada pendekatan saintifik. Mengkomunikasikan melatih anak mengembangkan sikap jujur, teliti, toleransi, kemampuan berpikir sistematis, mengungkapkan pendapat dengan singkat dan jelas, dan mengembangkan kemampuan berbahasa yang baik dan benar.

Ali Nugraha (2005, hlm. 129) mengemukakan mengkomunikasikan meliputi kegiatan menempatkan datadata ke dalam beberapa bentuk yang dapat dimengerti oleh orang lain. Kegiatan ini melibatkan kemampuan dalam bentuk lisan, tulisan, gambar, grafik, dan persamaan.

Menurut Ali Nugraha (2005, hlm. 128) ada beberapa komponen keterampilan mengkomunikasikan, yaitu: a) mengutarakan suatu gagasan; b) mencatat kegiatan-kegiatan atau pengamatan yang dilakukan; c) menunjukkan hasil kegiatan; d) mendiskusikan hasil kegiatan; e) menggunakan berbagai sumber informasi; f) mendengarkan dan menanggapi gagasan-gagasan orang lain; g) melaporkan suatu peristiwa atau kegiatan secara sistematis yang jelas. Dari beberapa komponen tersebut ada beberapa komponen yang dapat dilakukan oleh anak, yaitu mengutarakan suatu gagasan, mendiskusikan hasil kegiatan, dan melaporkan suatu peristiwa atau kegiatan secara sistematis yang jelas.

\subsubsection{Pengertian Permainan Sains}

Permainan sains adalah sarana bereksperimen dalam berbagai hal yang melibatkan kemampuan panca indera dalam proses observasi atau mencari informasi tentang objek sains yang diamati. Permainan sains dapat menimbulkan kesenangan bagi anak karena anak dibebaskan untuk bereksperimen secara terkontrol.

Bermain dan sains sangat berkaitan. Keduanya membutuhkan pemikiran dan praktek. Taylor (1993, hlm. 182) mengatakan bahwa melalui kegiatan bermain sains, anak-anak membangun hal-hal positif seperti meniru peran, membangun sikap positif, memecahkan masalah dengan cara-cara yang fleksibel, menjadi lebih percaya diri dan mandiri, meningkatkan konsentrasi dan mengasah keterampilan, menjadi pemimpin dan anggota, mengurangi frustasi, mengembangkan keragaman dalam berpikir, dan banyak karakter positif yang dibangun dalam kegiatan ini.

\section{METODE PENELITIAN}

Penelitian ini menggunakan metode Penelitian Tindakan Kelas (PTK) jenis Kemmis-Taggart. Menurut Wibawa (dalam Taniredja, 2010, hlm. 15) 
Penelitian Tindakan Kelas (PTK) merupakan suatu penelitian yang mengangkat masalah-masalah aktual yang dihadapi oleh guru di lapangan . Arikunto (dalam Taniredja, 2010, hlm. 15-16) mengartikan bahwa penelitian tindakan kelas merupakan suatu pencermatan terhadap kegiatan belajar berupa sebuah tindakan, yang sengaja dimunculkan dan terjadi dalam sebuah kelas secara bersama. Tindakan tersebut diberikan oleh guru atau dengan arahan dari guru yang dilakukan oleh siswa. Sedangkan menurut Wiradmadja (dalam Taniredja, 2010, hlm. 16), penelitian tindakan kelas adalah bagaimana sekelompok guru dapat mengorganisasikan kondisi praktik pembelajaran mereka, dan belajar dari pengalaman mereka sendiri. Mereka dapat mencobakan suatu gagasan perbaikan dalam praktik pembelajaran mereka, dan melihat pengaruh nyata dari upaya itu.

Berdasarkan pendapat para ahli disimpulkan bahwa penelitian tindakan kelas adalah penelitian yang mengangkat masalah-masalah yang aktual yang dilakukan oleh para guru yang merupakan pencermatan kegiatan belajar yang berupa tindakan untuk memperbaiki dan meningkatkan praktik pembelajaran di kelas secara lebih profesional.

Model Kemmis dan McTaggart pada hakikatnya berupa perangkat-perangkat atau untaian-untaian dengan satu perangkat terdiri dari empat komponen yaitu perencanaan, tindakan, pengamatan, dan refleksi, yang keempatnya merupakan satu siklus (Depdiknas dalam Taniredja, dkk., 2010, hlm. 24).

Subjek penelitian adalah anak kelas B, tepatnya kelas B1 RA Al-Istiqomah Kota Tasikmalaya Tahun ajaran 2017/2018 pada Kelas B1 dengan jumlah anak 16 anak yang terdiri dari 9 anak laki-laki dan 7 anak perempuan. Pada Penelitian Tindakan Kelas (PTK) dibantu oleh guru kelas B1 yaitu Ibu Putri Irma Susanti, S.Pd. AUD sebagai observer dalam pelaksanaan penelitian ini. Objek penelitian adalah peningkatan keterampilan mengkomunikasikan melalui permainan Sains.

Instrumen penelitian yang digunakan untuk mengumpulkan data dalam penelitian ini adalah lembar observasi untuk anak dan guru.

Dalam penelitian ini terdapat tiga instrumen yang digunakan, yaitu lembar observasi guru dalam merencanakan pembelajaran, lembar observasi guru dalam pelaksanaan pembelajaran, dan lembar observasi peningkatan keterampilan mengkomunikasikan anak melalui permainan sains.

Teknik analisis data yang digunakan dalam penelitian ini adalah teknik dengan melakukan beberapa tahapan diantaranya reduksi data, display data, dan verifikasi,

Keberhasilan penelitian tindakan kelas ditandai dengan adanya perubahan menuju arah yang perbaikan. Berikut merupakan indikator keberhasilan pada penelitian ini :

1) Guru mengalami peningkatan kemampuan dalam merencanakan pembelajaran khususnya pada peningkatan keterampilan mengkomunikasikan melalui permainan sains sekurang-kurangnya $75 \%$ dan berada pada kriteria baik.

2) Guru mengalami peningkatan kemampuan dalam melaksanakan pembelajaran khusunya pada peningkatan keterampilan mengkomunikasikan melalui permainan sains sekurang-kurangnya $75 \%$ dan berada pada kriteria baik.

3) Anak mengalami peningkatan dalam keterampilan mengkomunikasikan melalui permainan sains, ketika anak telah mencapai indikator 
keberhasilan yang telah ditentukan yaitu sekurang-kurangnya anak berada pada kriteria Berkembang Sesuai Harapan (BSH).

Langkah-langkah prosedur penelitian dilakukan minimal tiga siklus. Berikut prosedur penelitian dilaksanakan seperti prosedur di bawah ini.

1) Tindakan siklus I : perencanaan tindakan pembelajaran, pelaksanaan tindakan pembelajaran, observasi pelaksanaan tindakan, dan refleksi.

2) Tindakan siklus II: perencanaan tindakan pembelajaran, pelaksanaan tindakan pembelajaran, observasi pelaksanaan tindakan, dan refleksi.

3) Tindakan siklus III: perencanaan tindakan pembelajaran, pelaksanaan tindakan pembelajaran, observasi pelaksanaan tindakan, dan refleksi.

\section{HASIL DAN PEMBAHASAN}

Penelitian mengenai peningkatan keterampilan mengkomunikasikan melalui permainan sains telah dilaksanakan dalam tiga siklus. Sebelum dilaksanakan pra tindakan terlebih dahulu pada tanggal 2 Mei 2018. Siklus I dilaksanakan pada tanggal 8 Mei 2018 dengan tema alam semesta sub tema gejala alam dan sub-sub tema pelangi dengan materi yang disampaikan mengenai warna-warna pelangi. Siklus II dilaksanakan pada tanggal 10 Mei 2018 masih dengan tema, sub tema, dan sub-sub tema yang sama, namun pada siklus II materi yang disampaikan mengenai ciri-ciri pelangi dan menyanyikan lagu tentang pelangi. Siklus III dilaksanakan pada tanggal 14 Mei 2018 dengan tema, sub tema, dan sub-sub tema yang sama namun materi yang disampaikan mengenai jumlah warna pelangi.

Kemampuan guru dalam merencanakan pembelajaran mengalami peningkatan, hal ini terjadi karena adanya perbaikan-perbaikan yang dilakukan oleh guru. Data hasil observasi penilaian perencanaan pembelajaran pada siklus I masih banyak kekurangan yaitu dalam aspek perencanaan kegiatan bidang pengembangan, perencanaan pengelolaan kegiatan, dan perencanaan penilaian proses dan hasil. Pada siklus I kemampuan guru dalam merencanakan pembelajaran adalah $50 \%$ dengan kriteria cukup. Kekurangan pada siklus I diperbaiki dalam perencanaan pembelajaran pada siklus II. Pada siklus II beberapa kekurangan pada siklus I sudah diperbaiki namun masih perlu diperbaiki dan ditingkatkan lagi. Pada siklus II kemampuan guru dalam perencanaan pembelajaran adalah $60 \%$ dengan kriteria baik. Kekurangan pada siklus II diperbaiki di siklus III, sehingga peningkatan kemampuan guru dalam merencanakan pembelajaran sudah mencapai kriteria sangat baik, yaitu $81 \%$.

Peningkatan kemampuan guru dalam merencanakan pembelajaran dari siklus I, siklus II, ke siklus III dapat dilihat pada gambar berikut ini:

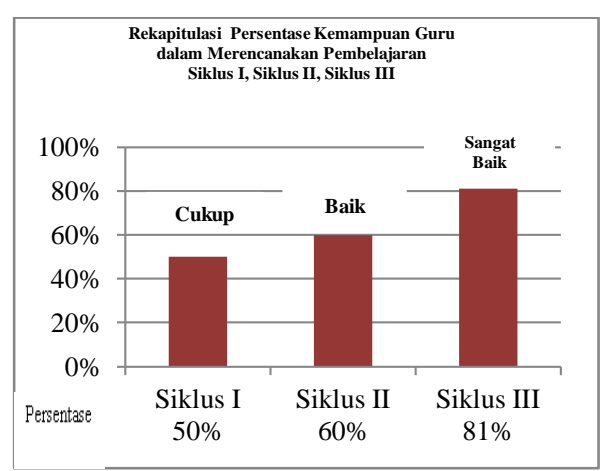

Gambar 4.1 Hasil Rekapitulasi

Kemampuan Guru dalam Merencanakan Pembelajaran

Siklus I, Siklus II, dan Siklus III

Pelaksanaan pembelajaran melalui permainan sains untuk meningkatkan keterampilan mengkomunikasikan anak di kelompok B RA Al-Istiqomah. Pada 
siklus I merupakan tahap persiapan kegiatan pembelajaran melalui permainan sains diperoleh kekurangan yaitu dalam mengkondisikan anak masih kurang menguasai sehingga anak tidak kondusif. Jadi kemampuan guru dalam pembelajaran melalui permainan sains pada siklus I yaitu mencapai skor 24 berada dalam kriteria cukup.

Kekurangan pada siklus I tersebut sudah diperbaiki pada siklus II, yaitu guru sudah mampu mengkondisikan anak. Pada siklus II merupakan tahap pelaksanaan dari permainan sains yang sebelumnya sudah direncanakan pada siklus I, diperoleh kekurangan pada siklus II yaitu guru kurang memotivasi dan membimbing anak saat melaksanakan pembelajaran melalui permainan sains sehingga anak kurang terlibat secara aktif. Kemampuan guru pada siklus II mencapai skor 31 berada dalam kriteria baik.

Pada siklus III merupakan tahap penilaian dari kegiatan pembelajaran melalui permainan sains, kekurangan pada siklus II sudah diperbaiki pada siklus III, jadi kemampuan guru dalam kegiatan pembelajaran melalui permainan sains mencapai skor 40 berada pada kriteria sangat baik.

Kegiatan pembelajaran melalui permainan sains dapat meningkatkan keterampilan mengkomunikasikan seperti yang dikemukakan Slamet Suyanto (2005, hlm. 83) Sains dapat melatih anak untuk menggunakan kemampuan panca indera, melatih menghubungkan sebab-akibat, megajarkan anak menggunakan alat ukur, melatih anak untuk menemukan dan memahami peristiwa serta memahami konsep-konsep benda. Dengan bermain sains, anak dapat melakukan hal-hal positif untuk membangun pengetahuannya serta meningkatkan keterampilannya, salah satunya adalah keterampilan mengkomunikasikan.

Peningkatan kemampuan guru dalam melaksanakan pembelajaran melalui permainan sains dari siklus I, siklus II, dan siklus III dapat dilihat pada gambar berikut ini:

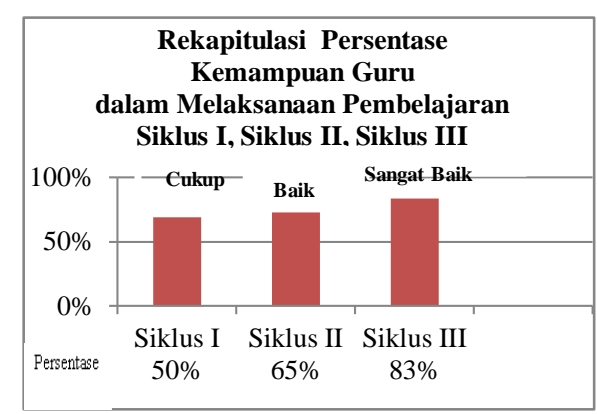

Gambar 4.2 Hasil Rekapitulasi Kemampuan Guru dalam Melaksanaan Pembelajaran melalui Permainan Sains Siklus I, Siklus II, Siklus III

Kegiatan pembelajaran melalui permainan sains dapat meningkatkan keterampilan mengkomunikasikan seperti yang dikemukakan Slamet Suyanto (2005, hlm. 83) Sains dapat melatih anak untuk menggunakan kemampuan panca indera, melatih menghubungkan sebab-akibat, megajarkan anak menggunakan alat ukur, melatih anak untuk menemukan dan memahami peristiwa serta memahami konsep-konsep benda. Dengan bermain sains, anak dapat melakukan hal-hal positif untuk membangun pengetahuannya serta meningkatkan keterampilannya, salah satunya adalah keterampilan mengkomunikasikan.

Peningkatan keterampilan mengkomunikasikan dari mulai siklus I, siklus II, dan siklus III dapat dilihat pada gambar 4.3 dan 4.4 sebagai berikut: 


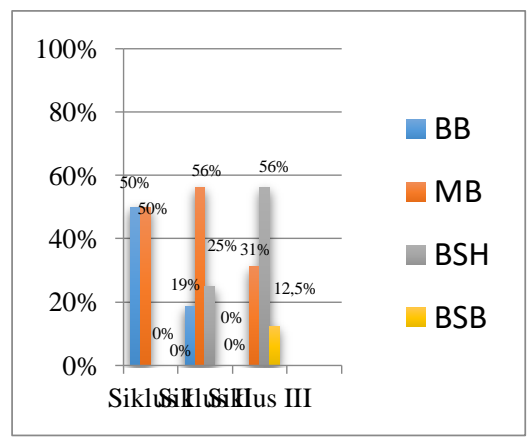

Gambar 4.3 Hasil Rekapitulasi

Keterampilan Mengkomunikasikan Verbal

Siklus I, Siklus II, Siklus III

Dapat dilihat pada gambar 4.3 indikator mengkomunikasikan verbal, pada siklus I terdapat delapan anak termasuk kedalam kriteria Belum Berkembang (BB) dengan persentase $50 \%$ dan delapan anak termasuk kedalam kriteria Mulai Berkembang (MB) dengan persentase $50 \%$. Pada siklus II terdapat tiga anak termasuk kedalam kriteria Belum Berkembang (BB) dengan persentase $18,75 \%$, sembilan anak termasuk kedalam kriteria Mulai Berkembang (MB) dengan persentase $56,25 \%$, dan empat anak termasuk kedalam kriteria Berkembang Sesuai Harapan (BSH) dengan persentase 25\%. Pada siklus III terdapat lima anak yang termasuk kedalam kriteria Mulai Berkembang (MB) dengan persentase $31,25 \%$, sembilan anak termasuk kedalam kriteria Berkembang Sesuai Harapan (BSH) dengan persentase $56,25 \%$, dan dua anak termasuk kedalam kriteria Berkembang Sangat Baik (BSB) dengan persentase $12,5 \%$.

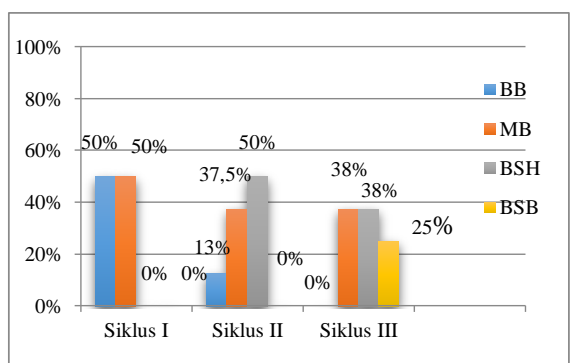

Gambar 4.4 Hasil Rekapitulasi

Keterampilan Mengkomunikasikan Non Verbal

Siklus I, Siklus II, Siklus III

Dapat dilihat pada gambar 4.4 indikator mengkomunikasikan non verbal, pada siklus I terdapat delapan anak termasuk kedalam kriteria Belum Berkembang (BB) dengan persentase $50 \%$ dan delapan anak termasuk kedalam kriteria Mulai Berkembang (MB) dengan persentase 50\%. Pada siklus II terdapat dua anak termasuk kedalam kriteria Belum Berkembang (BB) dengan persentase $12,5 \%$, enam anak termasuk kedalam kriteria Mulai Berkembang (MB) dengan persentase $37,5 \%$, dan delapan anak termasuk kedalam kriteria Berkembang Sesuai Harapan (BSH) dengan persentase 50\%. Pada siklus III terdapat enam anak yang termasuk kedalam kriteria Mulai Berkembang (MB) dengan persentase $37,5 \%$, enam anak termasuk kedalam kriteria Berkembang Sesuai Harapan (BSH) dengan persentase 37,5\%, dan empat anak termasuk kedalam kriteria Berkembang Sangat Baik (BSB) dengan persentase $25 \%$.

Data pada gambar 4.3 dan 4.4 menunjukkan bahwa keterampilan mengkomunikasikan anak mengalami peningkatan setelah menggunakan kegiatan pembelajaran melalui permainan sains. Secara umum keseluruhan aspek kinerja guru dan perkembangan keterampilan mengkomunikasikan anak dari siklus I, siklus II, siklus III dapat dikatakan berhasil walaupun tingkat 
pencapaiannnya belum maksimal. Pada pembelajaran siklus III peningkatan keterampilan mengkomunikasikan melalui permainan sains yang terdiri dari persiapan dengan membuat RPPH, pelaksanaan kegiatan pembelajaran melalui permainan sains telah meningkat secara optimal. Oleh karena itu, penelitian dihentikan hingga siklus III karena keterampilan mengkomunikasikan anak sudah meningkat sesuai dengan indikator keberhasilan yang telah ditentukan. Dengan demikian dapat disimpulkan bahwa permainan sains dapat meningkatkan keterampilan mengkomunikasikan anak di kelompok B RA Al-Istiqomah Kota Tasikmalaya.

\section{KESIMPULAN, IMPLIKASI, DAN REKOMENDASI}

Berdasarkan hasil Penelitian Tindakan Kelas yang dilaksanakan melalui beberapa tindakan dari siklus I, siklus II, siklus III mengenai penerapan permainan sains untuk meningkatkan keterampilan mengkomunikasikan anak di kelas B TK Al-Istiqomah RA Tasikmalaya, dapat diperoleh kesimpulan sebagai berikut:

1. Kemampuan guru dalam merancang perencanaan pembelajaran melalui permainan sains untuk meningkatkan keterampilan mengkomunikasikan anak mengalami peningkatan pada setiap siklus sesuai dengan indikator keberhasilan yaitu sekurangkurangnya berada pada kriteria baik. Perolehan hasil persentase pada siklus I adalah 50\% dengan kriteria cukup, persentase pada siklus II adalah $60 \%$ dengan kriteria baik, dan persentase pada siklus III adalah $81 \%$ dengan kriteria sangat baik.

2. Kemampuan guru dalam melaksanakan pembelajaran melalui permainan sains untuk meningkatkan keterampilan mengkomunikasikan anak mengalami peningkatan pada setiap siklus sesuai dengan indikator keberhasilan yaitu sekurangkurangnya berada pada kriteria baik. Perolehan hasil persentase pada siklus I adalah 50\% dengan kriteria cukup, persentase pada siklus II adalah $65 \%$ dengan kriteria baik, dan persentase pada siklus III adalah $83 \%$ dengan kriteria sangat baik. Meningkatnya kemampuan guru dalam menerapkan pembelajaran melalui permainan sains dikarenakan telah melakukan refleksi pada setiap siklusnya.

3. Peningkatan pada aspek perencanaan dan pelaksanaan pembelajaran berdampak pada peningkatan keterampilan mengkomunikasikan. Hal ini ditunjukkan dengan hasil observasi pada setiap indikator mengalami peningkatan dari mulai siklus I, siklus II, siklus III. Keterampilan mengkomunikasikan anak mengalami peningkatan setelah menggunakan kegiatan pembelajaran melalui permainan sains pada proses pembelajaran selama tiga siklus penelitian, peningkatan yang terjadi sudah mencapai indikator keberhasilan yang telah ditentukan yaitu sekurang-kurangnya anak berada pada kriteria Berkembang Sesuai Harapan (BSH).

Implikasi dari penelitian ini yaitu:

1. Memberikan informasi mengenai kegiatan pembelajaran melalui permainan sains dapat meningkatkan keterampilan mengkomunikasikan anak.

2. Memotivasi guru untuk menciptakan inovasi dalam pembelajaran yang lebih efektif sehingga keterampilan mengkomunikasikan anak dapat berkembang secara optimal.

3. Memberikan gambaran kepada guru dalam merancang pembelajaran melalui permainan sains. 
Adapun rekomendasi untuk penelitian ini yaitu:

1. Bagi Guru

Proses pembelajaran uang dilakukan guru dapat dijadikan landasan bahwa kegiatan pembelajaran pada anak usia dini tidak hanya dilakukan duduk didalam kelas, tetapi anak juga dapat belajar mengenai apa yang ada di sekitarnya dan mencoba hal-hal baru. Guru dapat memilih kegiatan yang tepat untuk digunakan dalam proses pembelajaran di kelas dan memberi rasa senang kepada anak juga sesuai dengan kebutuhan anak. Khususnya kegiatan yang dapat meningkatkan keterampilan mengkomunikasikan anak, salah satunya adalah permainan sains Rainbow Water.

2. Bagi Sekolah

Diharapkan sekolah memberikan sarana dan prasarana untuk menunjang kegiatan pembelajaran yang sesuai dengan dan kebutuhan anak, sehingga keterampilan mengkomunikasikan anak dapat berkembang secara optimal.

3. Bagi Peneliti Lainnya

Penelitian mengenai peningkatan keterampilan mengkomunikasikan melalui permainan sains pada proses pembelajaran ini masih mempunyai banyak kekurangan yang harus diperbaiki. Peneliti selanjutnya dapat melakukan inovasi dengan menerapkan kegiatan yang lebih efektif. Sehingga anak semakin antusias dalam mengikuti kegiatan pembelajaran.

\section{DAFTAR PUSTAKA}

Ambarsari, Desi. (2016). Jurnal Pendidikan Guru Sekolah Dasar Edisi 12 Tahun ke-5 2016. PGSD FIP: Universitas Negeri Yogyakarta.

Arikunto, Suharsimi. (2006). Prosedur Penelitian suatu Pendekatan Praktik. Jakarta: Rineka Cipta.

Arunna, Uchi. (2017, 3 Desember). "Pendekatan Saintifik Kurikulum 2013". Wordpress.com.

Barata, Atep Adya. (2003). Dasar-dasar Pelayanan Prima. Jakarta: Elex Media Komputindo.

Bondy \& Frost. (2002). Berbicara dan Berkomunikasi. Jakarta: Gramedia.

Dimyati, Johni. (2013). Metodologi Penelitian Pendidikan dan Aplikasinya pada Pendidikan Anak Usia Dini (PAUD). Jakarta: Kencana Prenada Media Group.

Gewati, Mikhael. (2018, 25 April). "Siapkan Pendidikan Anak yang Berkualitas". Kompas.com.

Hadsari, N. (2014) Peningkatan Keterampilan Mengkomunikasikan Sains melalui Media Grafis pada anak Kelompok B TK ABA Balerante Sleman Yogyakarta. (Skripsi. Sekolah Sarjana, Universitas Negeri Yogyakarta. Yogyakarta.

Idrus, Muhammad. (2009). Metode Penelitian Ilmu Sosial, Pendekatan Kualitatif dan Kuantitatif. Jakarta: Erlangga.

Ismail, Andang. (2009). Education Games: Menjadi Cerdas dan Ceria dengan Permainan Edukatif. Yogyakarta: Pilar Media.

Nugraha, Ali. (2005). Pengembangan Pembelajaran Sains pada Anak Usia Dini. Jakarta: Dirjen Dikti Depdiknas.

Nulfita, I. M. (2014, December). Implementasi Pendekatan Saintifik dan Karakter dalam Pembelajaran Sains Menyongsong Generasi Emas Indonesia. In Prosiding SNPS 
(Seminar Nasional Pendidikan Sains) (Vol. 1).

Palenewen, Evie. (2012). Pengembangan Model Pembelajaran Sains melalui Bermain di Taman Kanak-kanak. Jurnal Pendidikan Anak Usia Dini. 6 (2)

Rahayu, E., Susanto, H., \& Yulianti, D. (2011). Pembelajaran Sains dengan Pendekatan Keterampilan Proses untuk Meningkatkan Hasil Belajar dan Kemampuan Berpikir Kreatif Siswa. Jurnal Pendidikan Fisika Indonesia. 7 (2).

Riduwan. (2004). Metode Riset. Jakarta: Rineka Cipta.

Roza, M.M. (2012). Pelaksanaan Pembelajaran Sains Anak TK Aisyiyah Bustanul Athfal 29 Padang. Jurnal Pesona PAUD, 1(05).

Semiawan, Conny R, dkk. (1985). Pendekatan Keterampilan Proses: bagaimana mengaktifkan siswa dalam belajar. Jakarta: Gramedia.

Sendjaja, S. Djuarsa. (1994). Teori Komunikasi. Jakarta: Universitas Terbuka.

Sugiyono (2013). Metode Peneltitian Pendidikan (Pendekatan Kuantitatif, Kualitatif, dan R\&D). Bandung.

Sujiono, Y., Nurani. (2013). Konsep Dasar Pendidikan Anak Usia Dini. Jakarta: PT Indeks.
Suyanto, Slamet. (2005). Dasar-dasar Pendidikan Anak Usia Dini. Yogyakarta: Hikayat.

STPPA. 2014. Peraturan Mentri Pendidikan dan Kebudayaan Nomor 137 Tahun 2014 Tentang Standar Nasional PAUD.

Taniredja, dkk . (2010). Penelitian Tindakan Kelas. Bandung: Alfabeta, cv.

Trianto. (2012). Model Pembelajaran Terpadu. Jakarta: PT Bumi Aksara.

UU RI. 2003. Undang-Undang Republik Indonesia Nomor 20 Tahun 2003 Tentang Sistem Pendidikan Nasional.

Widyasari, dkk. (2014). Pendekatan Kemampuan Sains melalui Pendekatan Proyek. Jurnal Pendidikan Usia Dini. (vol.8)

Yulianti, Dwi. (2010). Bermain Sambil Belajar Sains di Taman Kanakkanak. Jakarta: PT Indeks. 